\title{
韓国政府による「伝統武芸」の創造： 2008年「伝統武芸振興法」の制定をめぐって
}

\author{
朴周鳳
}

JooBong Park: The invention of Korean Traditional Martial Arts: Enactment of the Traditional Martial Arts Promotion Law in 2008. Japan J. Phys. Educ. Hlth. Sport Sci. 55: 125-135, June, 2010

\begin{abstract}
The Korean government introduced the Traditional Martial Arts Promotion Law in 2008, which was the first governmental bill aimed at the preservation and promotion of Korean traditional martial arts. The law consists of 6 articles, including the definition of Korean traditional martial arts, the necessity of a master plan for their promotion, provision of support for traditional martial arts groups, and the fostering of leaders. This paper outlines the process of establishment of this law and attempts to clarify how Korean martial arts were conceptualized, authorized and invented as a Korean cultural tradition.
\end{abstract}

Key words : Korean martial arts, Traditional Martial Arts Promotion Law, governmental support キーワード：韓国マーシャル・アーツ，伝統武芸振興法, 政府支援

\section{1.はじめに}

2008年 3 月 28 日，韓国で「伝統武芸振興法」 （法律第9006号：以下，武芸振興法）という法律 が制定された。法文は全 6 条で構成された短い ものであるが，これまでになかった伝統武芸を政 府の次元で中長期的に保存 ·育成することを目的 とした初めての法律であった。

韓国のマーシャル・アーツにとって意味深いこ の法律の提案理由については伝統武芸振興法の提 案書に「伝統武芸はこれまで多くの戦乱において 国を守り，民族を統合させた護国精神と民族精気 を多分に含む伝統文化であるにも関わらず，近 年, 西洋からもたらされたスポーツ文化に凌駕さ れ，放置されている状態にある，それ故，伝統武 芸は我々の文化遺産として保存・継承するべきで あり，伝統武芸の振興のため国や地方自治団体に よる支援の法的根拠を作って我々の伝統文化を取 り戻し, さらに国民の健康増進と文化生活向上及

早稲田大学大学院人間科学研究科

干202-0021 東京都西東京市東伏見 2-7-5

早稲田大学東伏見キャンパス75-203

連絡先 朴周鳳
び文化国家建設に寄与したい」（Lee Si-jong, 2005）と書かれている.

韓国の伝統文化である武芸を保存・継承するた めの支援の根拠を創りたいという意図であった。

法案提出の背景となった韓国マーシャル・アー ツの一般的な状況については次のようである．韓 国では，2007年ごろまでマーシャル・アーツに 対する政府からの特別な扱いはなかった。むし ろ，マーシャル・アーツは体育とスポーツの枠の 中で扱われていたのであり，振興法でいう民族文 化や伝統文化として捉える動きはほとんど見られ なかった(注1).そして，さまざまな種目の団体に 対して，政府はもちろん民間の方でも，これをま とめる動きはなく，日本の「日本武道館」あるい は「日本古武道振興会」などといった武道や古武 道を統括する機関も存在しなかった．

現在, 韓国のマーシャル・アーツ種目は所属先 によって大きく 3 つに分けることができる．第 1 に専門スポーツ選手を育成し，オリンピックや世 界大会に向けた業務を担当する「大韓体育会」に

Graduate School of Human Sciences, Waseda University 75-203 Waseda University Higashi-fusimi Campus, 2-7-5 Higashi-fusimi, Nishi-tokyo, Tokyo, 202-0021 Corresponding author t11topjpy@yahoo.co.jp 
属しているもの，第 2 に国民の健康生活振興を 目的とした「国民生活体育会」（旧：国民生活体 育協議会）に属しているもの，そして第 3 にそ のどちらにも入らない種目である.

団体別の種目を見ると，「大韓体育会」（大韓体 育会，2008）には国際試合が行われる種目を中 心として「柔道」,「剣道」,「テコンドー」,「空手 道」,「ウーシュー」(中国の伝統武術), それに国 際試合は行わないが韓国の古くからのマーシャ ル・アーツと認識されている「シルム」(씨름 : 韓国式相撲)，「テッキョン」(택견 : 韓国伝来の マーシャル・アーツ, 柔らかい動きが特徵),「弓 道」が入っている。 また「国民生活体育会」には 「剣道」,「テコンドー」,「ウーシュー」,「テッキ ヨン」,「シルム」,「ハップキド」（함기도 : 合気 道とも書く. 柔を基本に打撃を使う流儀), 「国武 道」(素手格闘と剣・棒・槍・弓の武器術を使う 流儀),「総合武術」(テコンドー・合気道・柔道· ボクシング・剣道から長所だけ取り出した流儀) が属している．このように両団体には重複する種 目が多く見られるが，政府関係者の言によると， これは各種目がそれぞれの団体が定める選定基準 を満たした結果である。

そして，上揭 2 団体のいずれにも属さないも のとして「警護武術」(警護要員養成のための流 儀),「海東剣道」（真剣を使って主に太刀筋や形 を修練する流(義)，「ムエタイ」，「太極拳」，「24 班武芸」(朝鮮の兵法書である『武芸図譜通志』 をもとにする流儀),「特攻武術」(軍隊で敵を殺 傷するため考案された流儀）などがある.

また，それぞれの種目には多くの団体が存在し ているが, 団体の数やその実態については長らく 不明な状態であった。しかし2003年に国立民俗 博物館の主導で初めて国立ソウル大学スポーツ科 学研究所が韓国に現存して活動する団体に対する 調査を行った.

その報告書である『韓国の武芸団体現況』には， 各流派の所在地, 創始者, 継承体系, 現代表者の 履歴, 流派の履歴, 特徵, 修練体系, 重要用語, 昇段体系, 支部, 修練者の数, 事業計画などが調 査され, さらに代表者の顔や道場の風景, 技の写
真が掲載されている.

これによると, 種目と団体数は大きく剣道系 25団体, 警護武道系 8 団体, テコンドー系 5 団 体, テッキョン系 4 団体, 合気道系 19 団体, そ の他45団体，合計106団体が活動していることが 明らかになった。団体の選別は「文化体育観光部」 （元：文化観光部）に登録されている法人, 連盟, 協会を最優先として行い, さらに数十年間活動し ていることが確認できる団体を選んだという。し かし，あまりにも小さく少人数のクループと調査 に応じなかった団体は排除されたので，実際には もっと多くの団体が存在していると考えられる.

団体の数については, 文化体育観光部が 2008 年 8 月に発表した「生活体育法人現況」(注2)を見 ると, マーシャル・アーツ関連の種目は全部で 12 種目283団体に及んでいる。これを種目によっ て分類すると, 剣道系 62 団体, 格闘技系 13 団 体, 警護武道系 18 団体, 武術系 57 団体, ムエタ 1系 8 団体, 柔道系 2 団体, 伝統系 27 団体, テ コンドー系 38 団体, テッキョン系 4 団体, 特攻 武術系 3 団体, ハップキド系 47 団体, 他に 4 団 体が登録されている.

このように統計資料からはマーシャル・アーツ 団体の量的増加が明らかであり，年を経るごとに 新しい団体が創り出されていることがわかる.

このようにして韓国のマーシャル・アーツは， 政府系組織に入っている一部の種目や団体を除い て，すべてが自由に活動し，政府から統制される ことはなかった. 団体は政府の統制がない分, 政 府からの金銭的援助を含めた支援も受けなかった ため苦しい経済状態に置かれていた。 また韓国の マーシャル・アーツを体系づける理論を欠く状態 の下，各々の団体に抢いて個々に「他との比較に よる自派の優越性の誇示や秘伝性の強調, 論理的 飛躍, 日本武道の伝統を無意識的に受容する日本 化, 団体の性格や修練体系とは関係ない哲学的主 張，そして無分別な商業化」（国立民俗博物館, 2003）が行われることも指摘されている.

このように混乱する状況の中，マーシャル． アーツの種目とその団体に対する支援, 韓国マー シャル・アーツに概念化をもたらす「武芸振興法」 
が提出されたのである.

本研究は, 韓国で行われる新旧の多彩なマーシ ヤル・アーツに対して，政府が「伝統武芸」とい う新しい概念を導入することで独自の価值基準と 社会的位置づけをもたらすことになった「武芸振 興法」をとりあげ，その発議から施行までを再構 成しようとしている.

法案提出から制定まで新聞などのメディアでは ほとんど報道されておらず（中央日報；朝鮮日 報 ; 東亜日報; 韓国日報; 文化日報 ; 京郷新聞 ; 日刊スポーツ ; スポーツ朝鮮 ; スポーツ Seoul ; スポーツ Today ; スポーツ韓国 ; スポーツ東 亜; スポーツカン), その経緯を分析する研究も あまり試みられていない（Lee Jae-hak，2005;

Heo Keon-sik, 2008).

なお，本論文で扱う韓国語文献は筆者が日本語 に訳出している.「武芸振興法」の内容や武芸団 体名, 諸武芸に関する用語については, 現在ハン グル表記されているものの, 本来は漢字語である ため, 本論文においても「漢字」によって表記し た。また，武術，武芸，武道，格技などを総称す るための分析概念として, 本論文は英語のマーシ ヤル・アーツを用いることにする.

\section{2. 国会における「伝統武芸振興法」の 採択過程}

\section{1「伝統武術振興法」から「伝統武芸振興法」}

法案が初めて国会で発議されたのは2004年で ある、国会議員であるイ・シゾンらが伝統武術の 保存と振興を目的にする「伝統武術振興法」を発 議したのである。

しかし,「法案の審議過程で伝統武術の指定と 関連して一部の伝統武術団体が激しい反対活動を おこし, また文化財保護法と抵触する問題も指摘 され, 同法案の発議議員自らが法案撤回を申し出 た（2005年10月11日）」（国会文化観光委員会, 2005). そして，その後「撤回した法案の問題点 を解決して再び翌10月12日に伝統武芸振興法案 として提出する」(上掲書, p. 16)ことになった.
次の〈表 1〉は武術振興法と武芸振興法の内容 を要約比較したものである.

このように武術振興法と武芸振興法の間にはい くつかの違いが見られる.

1つ目は「伝統武術」を「伝統武芸」に変えた ことである。

『伝統武芸振興法案検討報告書』（以下，検討報 告書) には，「わが国では，武術は中国式用語， 武芸は韓国式用語, 武道は日本式用語として一般 的に理解するが, 武術, 武芸, 武道という 3 つ の概念はそれぞれ発展の段階に対応しており，つ まり実用的目的だけを重視する『術』から，技の ための技の追求或いは技の極致を追求する『芸』 へ，そして技を通じて哲学的精神を追求する『道』 に至るとするのが一般的な見解」(同書, p. 22) であると示されている.

そして,「わが国の場合は, 『武芸』という用語 によって『伝統体育』の一つの形態である『武芸 活動』を表すことで，日本や中国のものとは区別 される独自性が確保できる」(同書, p. 22) と評 価し，伝統武芸という言葉の適切性を表した.

2 つ目は法案の制定目的から「保存」という用 語が削除された。これは現行の法律では伝統文化 の保存は「文化財保護法」がこれに当たるため, 文化財保護法との抵触を避けるための措置であっ た。

3 つ目は「韓国伝統武芸振興会」の設立である. まだマーシャル・アーツ団体に対する客観的な基 準がない状況の中では「国家的次元の伝統武術の 指定や伝統武術団体認定制度の導入は, 伝統武術 種目間の葛藤や分裂を増幅する恐れがある」（同 書，p. 18）として，この項目を削除したのであ る.

しかし，代わりに「民間機構の性格をもつ韓国 伝統武芸振興会を新しく設けることによって, 伝 統武芸団体の自律的な活動は保証しながら，これ に必要な経費を国なた地方自治体が支援できるよ うにした」(同書，p. 19）のである.さらにこの 姿勢は国庫支援の項目にも現われ, 国による直接 的な支援ではなく, 韓国伝統武芸振興会やその参 加団体に支援する方向を決め，これから生じる混 
表 1 伝統武術振興法と伝統武芸振興法の比較

（国会文化観光委員会『伝統武芸振興法案検討報告書』，2005年11月）

\begin{tabular}{|c|c|c|}
\hline 区分 & $\begin{array}{c}\text { 伝統武術振興法案（撤回） } \\
\langle 2005.10 .11\rangle\end{array}$ & $\begin{array}{c}\text { 伝統武芸振興法案 (発議) } \\
\langle 2005.10 .12\rangle\end{array}$ \\
\hline 目的 & 「伝統武術の保存‧振興」 & 「伝統武芸の振興」 \\
\hline 振興対象 & 「伝統武術」 & 「伝統武芸」 \\
\hline 機構新設 & $\begin{array}{l}\text { 「伝統武術審議委員会」 } \\
\text { 「文化観光部長官に所属」 }\end{array}$ & $\begin{array}{l}\text { 「韓国伝統武芸振興会」 } \\
\text { 「文化観光部長官が印可」 }\end{array}$ \\
\hline 重要機能 & $\begin{array}{l}\text { ・「伝統武術の指定と解題」 } \\
\text { ・「伝統武術団体の認定とその解題」 } \\
\text { ・「伝統武術保存 ·振興基本計画の樹立」 } \\
\text { ・「伝統武術保存·振興の研究·調査」 } \\
\text { ・「伝統武術指導者の教育・養成」 }\end{array}$ & $\begin{array}{l}\text { ・「伝統武芸に関する基本計画及び細部施行 } \\
\text { 計画の樹立のための資料の調査・研究」 } \\
\text { ・「基本計画及び細部施行計画に従う事業の } \\
\text { 執行」 }\end{array}$ \\
\hline $\begin{array}{l}\text { 振興法の為の) } \\
\text { 基本計画樹立 } \\
\text { (文化観光部) }\end{array}$ & $\begin{array}{l}\text { ・「伝統武術の保存及び振興の基本方向」 } \\
\text { ・「伝統武術の保存及び振興, 調査・研究」 } \\
\text { ・「伝統武術団体に対する支援」 } \\
\text { ・「伝統武術関連資料の収集」 } \\
\text { ・「伝統武術指導者の教育・養成」 } \\
\text { ・「伝統武術の国際交流・協力及び国際行事 } \\
\text { 開催」 } \\
\text { ・「伝統武術振興に必要な財源の確保及び効 } \\
\text { 率的な運用法案」 }\end{array}$ & $\begin{array}{l}\text { ・「伝統武芸振興の基本方向」 } \\
\text { ・「伝統武芸の調査・研究」 } \\
\text { ・「伝統武芸育成種目の指定及び支援」 } \\
\text { ・「伝統武芸指導者の教育・養成」 } \\
\text { ・「伝統武芸の交流・協力及び大会開催」 } \\
\text { ・「伝統武芸の国際的交流・協力及び大会開 } \\
\text { 催」 } \\
\text { ・「伝統武芸振の興に必要な財源の確保及び } \\
\text { 効率的な運用法案」 }\end{array}$ \\
\hline 指定及び団体認定 & $\begin{array}{l}\text { ・「文化観光部長官が審議議院会の審議を通 } \\
\text { じて伝統武術指定及び伝統武術団体認定を } \\
\text { 行う」 }\end{array}$ & なし \\
\hline 指導者 & $\begin{array}{l}\text { ・「伝統武術団体の推薦を受け，文化観光部 } \\
\text { 令が定めた所定の教育と検定試験に合格し } \\
\text { た者」 }\end{array}$ & $\begin{array}{l}\text { ・「学校, 職場, 地域社会などで伝統武芸を } \\
\text { 指導する者として, 大統領が定めた所定の } \\
\text { 教育と検定試験に合格した者」 }\end{array}$ \\
\hline 国庫支援 & ・「伝統武術団体に対する国庫支援」 & $\begin{array}{l}\text { •「韓国伝統武芸振興会及び傘下団体に対す } \\
\text { る国庫支援」 }\end{array}$ \\
\hline
\end{tabular}

乱を避けようとしたのであった。

\section{2 伝統武芸振興法の制定へ}

2005年10月, 再び発議された武芸振興法は, 同年11月17日，第256回国会（定期会）第13次文 化観光委員会に上程され提案理由の説明のあと審 議が行われた。そして，法案審査小委員会に回付 された．その後，2008年 2 月 22 日，第271回国会 （臨時会）で第 1 次法案審査小委員会と第 5 次文 化観光委員会から修正可決という結果を得た.

そして，同年 3 月 28 日，法律第9006号として 「伝統武芸振興法」が制定された。

〈表 2〉は武芸振興法の2005年の原案と2008年
の修正可決案を比較したものである.

修正された法案はそのまま正式な法律として定 められた．内容的には最初の原案と重なるところ が多く，元の法案の組久合わせを変えて修正案に したものであった，ただし，削除したところも多 かったため, 法案はかなりシンプルな形に変わっ てしまった。

原案から変更された 1 目が伝統武芸の定義 の問題である. 原案では伝統武芸を国内で自生し たか海外から輸入されたもので文化的価值がある ものと定義したのに対し, 修正案ではさらに, 文 化財保護法によって重要無形文化財に指定されて 
表 2 原案と修正案の対比表

（国会文化観光委員会, 『伝統武芸振興法案一部改正法律案審査報告書』, 2008年 2 月）

\begin{tabular}{|c|c|}
\hline 原案（2005年） & 修正案（法律第9006号） \\
\hline $\begin{array}{l}\text { 第 } 1 \text { 条（目的）「この法は文化的価値がある伝統武芸を } \\
\text { 振興して，国民の健康増進と文化生活向上および文化国 } \\
\text { 家建設に寄与することを目的とする」 }\end{array}$ & $\begin{array}{l}\text { 第 } 1 \text { 条（目的）「この法は文化的価值がある伝統武芸を } \\
\text { 振興して, 国民の健康増進と文化生活向上および文化国 } \\
\text { 家建設に寄与することを目的とする」 }\end{array}$ \\
\hline 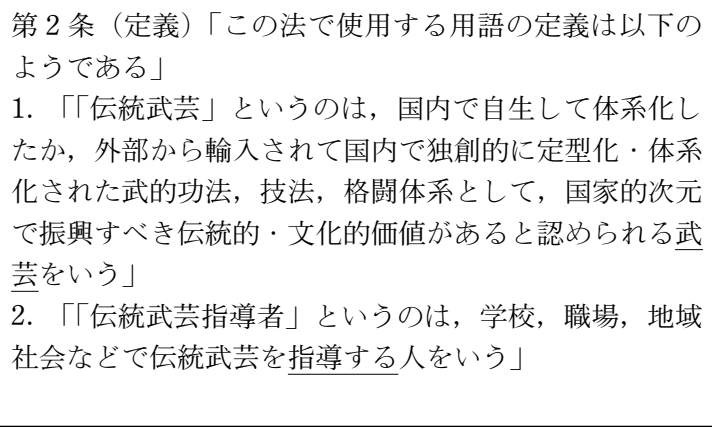 & 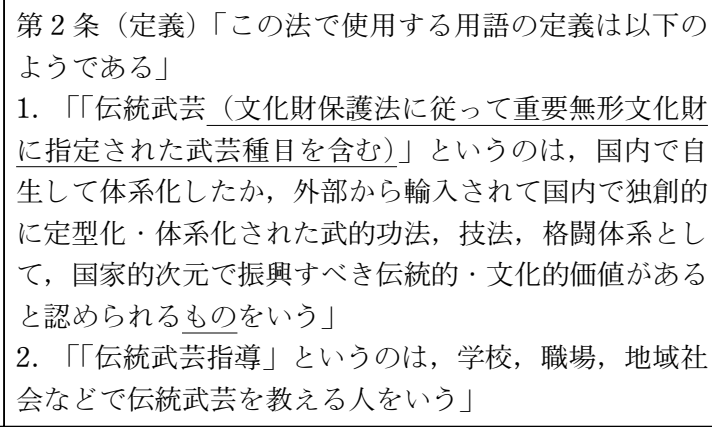 \\
\hline $\begin{array}{l}\text { 第 } 3 \text { 条「国家及び地方自治体の責務」 } \\
\text { (1)「国家及び地方自治団体は伝統武芸の振興のため各種 } \\
\text { の施策を樹立・施行しなければならない」 } \\
\text { (2)「国家及び地方自治体は国民の自発的な伝統武芸活動 } \\
\text { を奨励・保護及び育成し，そのために必要な施設の設 } \\
\text { 置, 人材と組織の確保及び予算の支援などの与件を助成 } \\
\text { しなければならない」 }\end{array}$ & 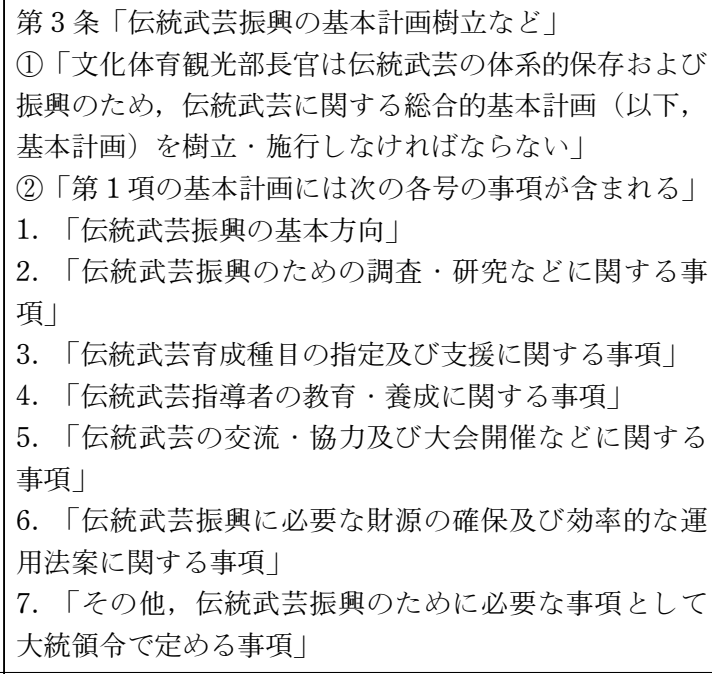 \\
\hline 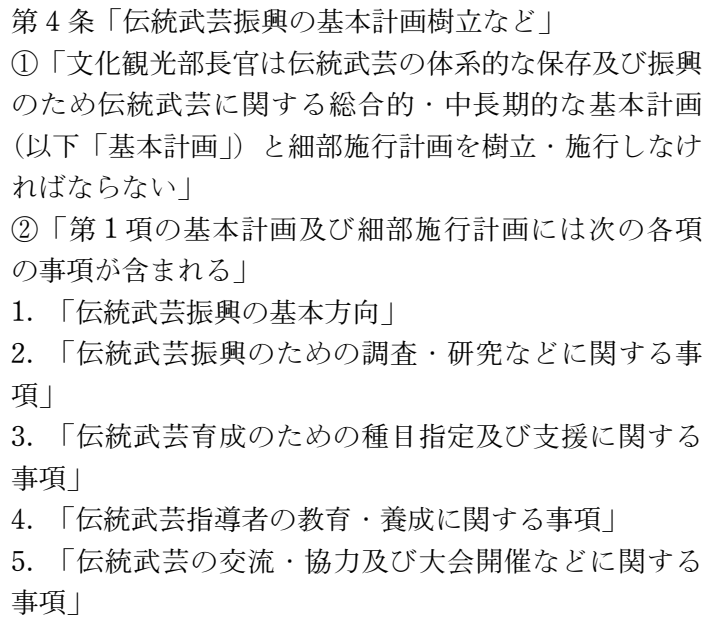 & $\begin{array}{l}\text { 第 } 4 \text { 条「国家および地方自治体の責務」 } \\
\text { (1)「国家および地方自治団体は基本計画に従って, 伝統 } \\
\text { 武芸の振興のため各種施策を樹立・施行しなければなら } \\
\text { ない」 } \\
\text { (2)「国家および地方自治体は国民の自発的な伝統武芸活 } \\
\text { 動を奨励・保護および有成し，そのために必要な施設の } \\
\text { 設置, 人材と組織の確保及び予算の支援などの与件を助 } \\
\text { 成するべきである」 }\end{array}$ \\
\hline
\end{tabular}


6.「伝統武芸の国際的な交流・協力及び大会開催など に関する事項」

7. 「伝統武芸振興のための必要な財源の確保及び効率 的な運用法案に関する事項」

8.「その他, 伝統武芸振興のために必要な事項として 大統領令で定める事項」

第 5 条「伝統武芸指導者育成」

(1)「文化観光部長官は伝統武芸振興のため伝統武芸指導 者の養成と資質向上のため必要な施策を講じなければな らない」

(2)「伝統武芸指導者の種類 ·等級 ·資格基準 ·研修 ·検 定及び資格付与などに関して必要な事項は大統領令で定 める」

第 6 条「韓国伝統武芸振興会の設立」

(1)「伝統武芸振興活動に関する次の各項の事業のため文 化観光部長官の認可を受け勧告伝統武芸振興会（以下， 振興会）を設立する」

1.「第 4 条の規定による基本計画及び細部施行計画樹 立のための資料調査・研究なぞ」

2.「基本計画及び細部施行計画による事業の執行」

第 5 条「伝統武芸団体の育成」

「国家及び地方自治団体は，伝統武芸振興のため伝統武 芸団体を育成・支援しなければならない」

3.「その他伝統武芸の振興のために必要と認められる 事業」

(2)「振興会を法人にし，定款の定めに従って伝統武芸の 種目別・地域別傘下団体を設けられる」

(3)「振興会の会員及び会費徵収に関して必要な事項は定 款で定める」

(4)「振興会の会長一人及び常任理事一人を含めた 20 人 以内の理事と監事を設ける」

(5)「振興会の会長は定款の定めに従って選出するが文化 観光部長官の承認を得て就任し, 常任理事は会長の推薦 を受け文化観光部長官が任命する」

(6)「会長は振興会を代表し振興会の業務を総括する」

(7)「常任理事は会長を補佐し，会長に事故ある時にはそ の職務を代行する」

8)「監事は振興会の業務及び会計を監査し，文化観光部 長官が任命する」

(9)「振興会は第 1 項の規定による目的事業に必要な経 費を調達するため，文化体育観光部長官の承認を得て収 益事業ができる」

(10「振興会に関しては，この法で規定したこと以外には 「民法」中の財団法人に関する規定を準用する」

第 7 条「振興会なぞに対する補助」

「国家及び地方自治体は振興会及び傘下団体に対して, 予算の範囲内で必要な経費の全部をたは一部を補助する ことができる」

第 8 条「会計監督など」

(1)「振興会は毎会計年度の事業計画と予算に関して，次 第 6 条「伝統武芸指導者育成」

(1)「文化体育観光部長官は伝統武芸の振興のため, 伝統 武芸指導者の養成と資質向上のため必要な施策を講じな ければならない」

(2)「伝統武芸指導者の種類・等級・資格基準 · 研修 · 検 定及び資格付与などに関して必要な事項は大統領令で定 める」

の各号の書類を添付して文化観光部長官の承認を得なけ ればならない」 
1.「事業運営計画書」

2. 「予算案」

(2)「振興会は第 1 項の規定による事業計画と予算を変 更する時は, その変更理由と変更内容が記載された書類 を添付して文化観光部長官に提出し承認を得なければな らない」

(3)「振興会は毎会計年度終了後 2 ヶ月以内に次の各号 の事業実績と決算報告書を文化観光部長官に提出しなけ ればならない」

1.「当年度の賃借対照表及び損益計算表」

2.「当年度の事業計画と実行実績対比表」

3.「公認会計士の検查意見書と監事の監查意見書」

4.「その他決算の内容が確認できる付則書類」

(4)「文化観光部長官は振興会に対して事業また財産状態 を監査など監督上に必要な命令を下すことができる」

「この法は公表後 6 ケ月が経過した日から䝯行する」

いる武芸種目を含むと定め, その適応範囲を広く したのである(第 2 条)、ただし現在重要無形文 化財に指定されている種目はテッキョン 1 つで ある。

2 つ目は, 本法案に関する基本計画の樹立や実 行する機関を国や地方自治体とする原案から文化 体育観光部長官と明確に定めたことである（第 3 条)、ただし, 伝統武芸団体の施策の施行や育成 など具体的な支援に関しては原案どおり国や地方 自治体が行うようにしている（第 4 条）。

3つ目は, 武芸振興法を実行する民間団体とし てあげられた「韓国伝統武芸振興会」の設立と構 造に関する条項が削除されたことである（原案 6 条)、これにより武芸振興会に対する経費の補助 (第 7 条) や会計監查など, 韓国伝統武芸振興会 に関する条項もすべて削除されることになった。

\section{3 伝統武芸振興法施行令の制定案}

武芸振興法は制定から 1 年間の期間を設け 2009年 3 月 29 日から施行することになったが， これに先立ち2009年 1 月 22 日に伝統武芸振興法 の施行令に対する制定案が本法案に関わる担当施 行機関である「文化体育観光部」から出された. これは, 武芸振興法の各条の実行において必要な
事項をさらに具体的に定めたものである.

〈表 3〉は武芸振興法とそれによる施行令を整 理したものである。

施行令の制定案は特に伝統武芸指導者に重点を 置いている (第 3 条). まず指導者の 18 歳以上と いう年齢制限と指導者の資質によって 1 級と 2 級に区分することを明記する，そして指導者の資 格に関して, 資格検定や研修, 資格証の発行に関 することを「文化体育観光部長官」が定め告示す るようにしているのである.

\section{3. 伝統武芸の概念化}

韓国では長らくマーシャル・アーツを表示する のに武術, 武芸, 武道, 格技などの語が不統一に 使用されていたが，今回の武芸振興法によって武 芸の語が韓国ではふさわしいと改めて定められ た. また武芸振興法の対象となる「伝統武芸（文 化財保護法で重要無形文化財に指定されている種 目を含む）というのは, 国内で自生して体系化し たか, 外部から輸入されて国内で独創的に定型 化·体系化された武的功法 ·技法 ·格闘体系とし て, 国家的次元で振興する伝統的・文化的価值が あると認められるものをいう」(法律第 9006 号, 
表 3 伝統武芸振興法施行令の制定案

（文化体育観光部，2009年 1 月）

\begin{tabular}{|c|c|}
\hline 振興法（法律第9006号） & 施行令（案） \\
\hline $\begin{array}{l}\text { 第 } 1 \text { 条（目的）「この法は文化的価值がある伝統武芸を } \\
\text { 振興して，国民の健康増進と文化生活向上および文化国 } \\
\text { 家建設に寄与することを目的とする」 }\end{array}$ & $\begin{array}{l}\text { 第 } 1 \text { 条（目的）「この令は「伝統武芸振興法」（以下， } \\
\text { 法）が定める事項の施行に必要な事項の規定を目的とす } \\
\text { る」 }\end{array}$ \\
\hline 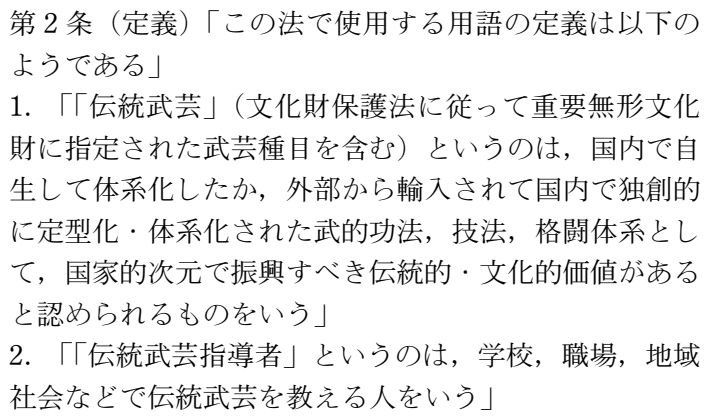 & \\
\hline 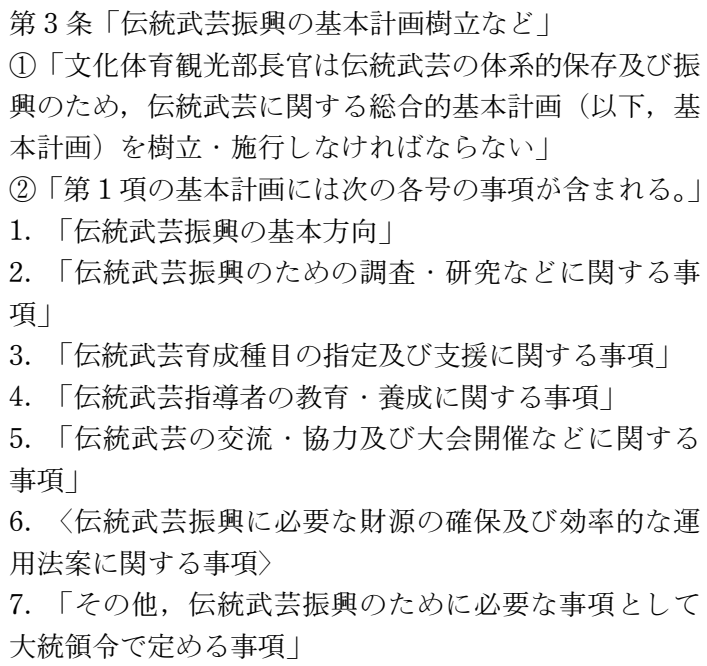 & $\begin{array}{l}\text { 第 } 2 \text { 条「伝統武芸振興計画の樹立」 } \\
\text { 1)「法第 } 3 \text { 条第 } 2 \text { 項第 } 7 \text { 号で「大統領令に定めた事項」 } \\
\text { は次の各号を示す」 } \\
\text { 1. 「伝統武芸発の掘及び育成」 } \\
2 . 「 \text { 全国規模での伝統武芸の支援及び競技大会の開催」 } \\
3 . 「 \text { 伝統武芸国際学術セミナー及び国際親善武芸競技 } \\
\text { 大会」 } \\
\text { (2)「文化体育観光長官は法第 } 3 \text { 条第 } 1 \text { 項による基本計 } \\
\text { 画を樹立した時には, 特別市長 ·広域市長をたは道知事 } \\
\text { (以下, 市・道知事) 及び市長 ·郡首・区庁長（自治区 } \\
\text { の区庁長をいう)に基本計画を通報しなければならない」 }\end{array}$ \\
\hline $\begin{array}{l}\text { 第 } 4 \text { 条「国家および地方自治体の責務」 } \\
\text { (1)「国家及び地方自治体は基本計画に従って, 伝統武芸 } \\
\text { の振興のため各種施策を樹立・施行しなければならない〉 } \\
\text { (2)「国家及び地方自治体は国民の自発的な伝統武芸活動 } \\
\text { を奨励・保護および㕕成し, そのために必要な施設の設 } \\
\text { 置, 人材と組織の確保及び予算の支援などの与件を助成 } \\
\text { しなければならない〉 }\end{array}$ & \\
\hline $\begin{array}{l}\text { 第 } 5 \text { 条「伝統武芸団体の育成」 } \\
\text { 「国家及び地方自治体は，伝統武芸振興のため伝統武芸 } \\
\text { 団体を育成・支援しなければならない」 }\end{array}$ & \\
\hline $\begin{array}{l}\text { 第 } 6 \text { 条「伝統武芸指導者育成」 } \\
\text { (1)「文化体育観光部長官は伝統武芸の振興のため, 伝統 } \\
\text { 武芸指導者の養成と資質向上のため必要な施策を講じな } \\
\text { ければならない」 } \\
\text { (2)「伝統武芸指導者の種類 ·等級 ·資格基準 · 研修・検 } \\
\text { 定及び資格付与などに関して必要な事項は大統領令で定 }\end{array}$ & $\begin{array}{l}\text { 第 } 3 \text { 条「伝統武芸指導者の種類など」 } \\
\text { (1)「法第 } 6 \text { 条第 } 2 \text { 項に従って伝統武芸指導者の資格は } \\
18 \text { 歳以上の者に付与し, 伝統武芸指導者の等級は } 1 \text { 級 } \\
\text { と } 2 \text { 級に区分する」 } \\
\text { (2)「1 級伝統武芸指導者は } 2 \text { 級伝統武芸指導者資格を取 } \\
\text { 得した後, 次の各号のいずれかが該当する者として, 文 }\end{array}$ \\
\hline
\end{tabular}


める」

化体育観光部長官が定めた資格検定に合格し研修を履修 した者とする，ただし，「文化財保護法」に従って重要 無形文化財武芸種目の重要無形文化財保有者として認め られた者は伝統武芸指導者 1 級資格を取得したことと する」

1. 「2 級伝統武芸指導者資格の取得後, 申請種目の選 手経歴や指導経歴が 2 年以上の者」

2.「第 1 号に規定された者と同じ水準以上の資格があ ると文化体育観光部長官が認めた者」

(3)「2 級伝統武芸指導者は次の各号のいずれかに該当す る者として文化体育観光部長官が定めた資格検定に合格 し，研修を履修した者とする，ただし，「文化財保護法」 に従って重要無形文化財武芸種目の重要無形文化財専修 教育助教として認められた者は伝統武芸指導者 2 級資 格を取得したこととする」

1.「次の各目の教育機関で文化体育観光部長官が定め た法定科目を履修した者」

ア.「高等教育法第 2 条による学校で単位を取得した 者」

1.「生涯教育法第 2 条第 2 号の生涯教育機関で単位 を取得した者」

2.「文化体育観光部長官が定めた伝統武芸団体の資格 証を取得した者」

3. 「文化財保護法による重要文化財指定種目の履修証 を取得した者」

4. 「第 1 号および第 2 号で規定した者と同じ水準以上 の資格があると文化体育観光部長官が認めた者」

(4)「伝統武芸指導者の資格検定及び研修，資格証発行な どに関して必要な事項は文化体育観光部長官が定めて告 示する」

(5)「資格検定及び研究を実施す機関長は文化体育観光部 長官の承認を得て, 資格検定および研修に必要な費用の 一部を資格検定および研修を受ける者に負担させること ができる」

第 2 条）と概念規定されたのである.

ところで，2003年に公刊された『韓国の武芸 団体現況』は伝統武芸を「我が民族に基盤を置い て長年の間続いて来た武芸の中でその価值を認め られたもの」（国立民俗博物館，上掲書，p. 30) と定義している.

これに対して『検討報告書』は「我が民族に基 盤を置いたということが何を意味するのか，長年 の間と言うのはどれくらいを意味するのか，そし
て誰から認められた価值を意味するのかなどの問 題は依然として解決しなければならない問題とし て残っている」（国会文化観光委員会, 上掲書, p.6）として『韓国の武芸団体現況』の概念の曖 昧さを指摘し，伝統武芸に対して「私たちの特殊 な文化風土と地理的与件，民族性などを土台に， 攻防の意味を含んだ動作を主要鍛錬内容とする套 路・攻法・格闘の修練形式を取り揃えて身体内外 をともに鍛えるもの」（同書, pp. 6-7）と提言し 
た。

『検討報告書』の定義によれば，発生地が国内 であれ外来であれ，韓国内で体系化され，套路・ 攻法・格闘の修練形式を備えてさえすれば伝統武 芸として認められ, 武芸振興法の適用対象になる ことになる.

また，この武芸振興法の主旨である伝統につい ては「『伝統』ということは『持続性』と『特異 性』だけでなく『可変性』と『現在性』を一緒に 持っていなければならない」(同書, p. 23) と説 明した上で，「伝統武芸を解釈するに扔いて偏狭 なナショナリズム的民族主義的解釈は警戒する必 要がある」(同書, p. 23) として, 伝統武芸の概 念を拡大したのであった。

伝統武芸という概念がこのように定められたこ とは, 韓国の武芸にとっては大きい意味を持つ. 今後, 韓国のマーシャル・アーツ界は政府が定め た基準に沿う形に在り方を変容させてゆくことが 考えられるからである。

\section{4. 伝統武芸振興法の施行後の 韓国武芸界の動き}

2009年 3 月武芸振興法施行に伴って, 一部で は施行後に向けた動きが始まっている.

例えば「海東剣道」である。これは新興であり ながら短期間で組織を拡大した成功団体として知 られて抢り，そして，その組織である「世界海東 剣道連盟」(以下, 海東連盟) からは多くの人材 が輩出され, 海東剣道系の諸団体が数多く作られ た。 そうした独立諸団体のいくつかが海東連盟に 戻る現象が見られたのである.

その 1 つが「全国海東剣道協会」であった。 ムカス (무카스: 武芸専門ウェブサイト) の記事 （2008年 9 月 9 日）によれば全国海東剣道協会は 2002 年 1 月に当時 20 個の道場をもって海東連盟 を離脱した団体であったが，2008年 9 月に復帰 を決定した，復帰理由として挙げられたのが，武 芸振興法の施行にともなう法的・経済的な支援を 得るためであり，また振興法によってマーシャ ル・アーツ団体に対する規制が強まるとの思いか
ら, 力のある団体と行動を共にして, 自身の位置 を安定させる狙いからであった。

また，海東連盟とライバル関係にあった「韓国 海東剣道協会」の指導者らが集合して「海東剣道 総連合会」を結成し, 海東連盟への転向を決めた のである (2008年 7 月 12 日)。その理由としてあ げられたのが，武芸振興法制定後も分立している 状況では多くの指導者が政府から支援を受けられ なくなり, 道場経営も厳しい状態に置かれるであ ろうという懸念であったが，これもやはり政府の 支援をとりつけるための行動であると考えられる.

さらに，その他の武芸団体による対応も見られ る. 例えば「伝承復元武芸」や「創始武芸」と武 芸振興法の主旨を意識した名前を揚げた武芸団体 が結成されたことが挙げられる。 また，それまで 個別に活動していた諸団体, 伝承復元武芸連合 会, 創始武芸連合会，テコンドー連合会，ハップ キド連合会, 剣道連合会, 特攻武術連合会, 警護 武術連合会は, 武芸振興法に対応するため「韓国 伝統武芸総連合会」を設立し，2009年 4 月に法 人許可をうけている.

\section{5. まとめ}

本研究では, 韓国で2008年 3 月に制定された 「伝統武芸振興法」をとりあげ，その内容の吟味， 法案提出から施行に至る過程, 施行によって生じ たマーシャル・アーツ界の対応が再構成された。 またその中で, 韓国のマーシャル・アーツが置か れている状況と武芸振興法の影響性が明らかにな った。

「武芸振興法」は韓国の伝統武芸支援を目的と して提出された初めての法律であり, そのための 基本計画の樹立や伝統武芸団体の支援，指導者の 養成などを定めている.

武芸振興法は韓国のマーシャル・アーツに大き な影響をもたらした。

それまで韓国には武術, 武芸, 武道, 格技など の語が共通理解もないままに，いわば恣意的に使 用されていたが，武芸振興法の中で政府が伝統武 芸という新しい概念を創造することで，公的な秩 
序と正当性が与えられることになったためである.

最後に「武芸振興法」はグローバルに展開する 国際スポーツが盛行する中にあって, 韓国マーシ ヤル・アーツを韓国の文化・思想を体現する民族 スポーツに変容させるきっかけを提供するもので あると認めてもよいであろう.

\section{注}

注 1)「我々の社会ではマーシャル・アーツに対する 関心はまだ周辺的で制限的である。・略…制限 的というのは, 武術, 武芸, 武道に関する研究を 重要と認識する者がきわめて少ないという意味で ある. …中略…周辺的というのは, 武術, 武芸, 武道に関する研究は体育界および体育学界, そし て韓国学また伝統文化の領域では中心テーマとし て扱われていないという意味である」（Kim Chang-yong et al., 2001, p. 62) という指摘がある.

注 2）この報告書は, 種目の分類, 団体の法人名, 設 立日, 代表者, 連絡先, 許可機関が記録されたも のであり, 地方自治体から報告されたものを文化 体育観光部がまとめたものである. 分類は団体名 称によるものが多い, 例えば種目を「剣道」とし た場合,「大韓剣道連合会」,「国際海東剣道協会」 など団体名に剣道という文字が入っているものが 含まれている，但し「武術」の場合は，「韓国少林 武術協会」,「韓国伝統武術協会」のように「武術」 を使う団体以外に「大韓古武道協会」,「大韓太極 拳協会」,「大韓空手道協会」,「大韓プロ拳法協会」 など，「武術」の文字がみられない団体を含めてお り，分類基準が不分明である.

\section{引用文献及び関連ウェブサイト}

文化体育観光部 $(2007,2008)$ 生活体育関連法人現況. 文化体育観光部：韓国.

文化体育観光部（2008，2009）伝統武芸振興法案 一 部改正法律案審査報告書, 「伝統武芸振興法 施行令 制定令（案) 」. 文化体育観光部：韓国.
大韓体育会 (2008) 加盟競技団体連絡先. 大韓体育会 : 韓国.

Heo, Keon-sik（2008）伝統武芸振興法の法理解釈と展 望. 大韓武道学会誌, $10(1): 41-56$.

Kim, Chang-yong., Yang, Jin-bang., and Heo, Keon-sik (2001) 武術, 武芸, 武道の用語正立のための課題. 龍仁大学校武道研究誌, $12(1)$ : 61-73.

国会文化観光委員会（2005）伝統武芸振興法案検討報 告書. 文化体育観光部 : 韓国

国立民俗博物館（2003）韓国の武芸団体現況. 国立民 族博物館 : 韓国.

Lee, Jae-hak（2005）韓国武道の近代的変遷過程に関 する研究. 龍仁大学校大学院体育学科博士論文. 龍 化大学校 : 韓国.

Lee, Si-jong (2005) 伝統武芸振興法案 議案番号2907. 文化体育観光部 : 韓国.

文化日報 http://www.munhwa.com/

中央日報 http://www.joins.com

朝鮮日報 http://www.chosun.com

東亜日報 http://www.donga.com/

韓国日報 http://www.hankooki.com/

京郷新聞 http://www.khan.co.kr/

国会法律知識情報システム

http://likms.assembly.go.kr/law/jsp/main.jsp

ムカス http://www.mookas.com/

日刊スポーツ http://isplus.joins.com/

スポーツ朝鮮 http://sports.chosun.com/

スポーツ東亜 http://sports.donga.com/

スポーツ韓国 http://sports.hankooki.com/

スポーッカン http://www.sportskhan.net/

スポーツ Seoul http://www.sportsseoul.com/

スポーツ Today http://stoo.asiae.co.kr/

$\left(\begin{array}{l}\text { 平成 } 21 \text { 年 } 9 \text { 月 } 24 \text { 日受付 } \\ \text { 平成 } 22 \text { 年 } 3 \text { 月 } 2 \text { 日受理 }\end{array}\right)$

Advance Publication by J-STAGE Published online 2010/04/23 